\title{
Optimization of Thermogravimetric Analysis of Ash Content in Honey
}

\author{
Maria L. Felsner ${ }^{a}$, Cristiane B. Cano ${ }^{b}$, Jivaldo R. Matos ${ }^{a}$, Lígia B. de Almeida-Muradian $^{c}$ \\ and Roy E. Bruns $*$,a,d \\ ${ }^{a}$ Instituto de Química, Universidade de São Paulo, Av. Prof. Lineu Prestes, 748 - Bloco 8, 05508900, \\ São Paulo - SP, Brazil \\ ${ }^{b}$ Seção de Bebidas, Instituto Adolfo Lutz, Av. Dr. Arnaldo 355, 01246-902 São Paulo - SP, Brazil \\ ${ }^{c}$ Faculdade de Ciências Farmacêuticas, Universidade de São Paulo, Av. Prof. Lineu Prestes, 580 - Bloco 14, \\ 05508-900 São Paulo - SP, Brazil
}

${ }^{d}$ Instituto de Química, Universidade Estadual de Campinas, CP 6154, 13083-970 Campinas - SP, Brazil

\begin{abstract}
Um planejamento fatorial foi aplicado para avaliar o conteúdo de cinzas em mel pela termogravimetria bem como para estabelecer as condições de análise ótimas que produzem conteúdos de cinzas em concordância com aqueles obtidos pelo método oficial (gravimetria). Os efeitos de taxa de aquecimento e papel de fibra de vidro foram significativos bem como o efeito de interação entre estas variáveis. Taxas de aquecimento e o emprego do papel de fibra de vidro são recomendados para obter a incineração completa de mel pela termogravimetria. Para confirmar estes resultados e estabelecer as condições otimizadas foi executado um planejamento completamente aleatorizado em blocos investigando três procedimentos: termogravimetria com papel de fibra de vidro a 5 e $10^{\circ} \mathrm{C} \mathrm{min}^{-1} \mathrm{e}$ gravimetria. Somente o método termogravimétrico realizada à $5{ }^{\circ} \mathrm{C} \mathrm{min}^{-1}$ apresentou conteúdos médios de cinzas em concordância com aqueles obtidos pelo método oficial. Assim, a TG/DTG pode ser indicada como um método alternativo à gravimetria para esta determinação em mel.
\end{abstract}

A factorial design to evaluate ash content in honey by thermogravimetry as well as to establish the optimum analysis conditions that produce ash values in agreement with those obtained by the official method (gravimetry) was executed. Heating rate and use of fiber glass paper effects were significant as was the interaction effect between them. Lower heating rates and the use of fiber glass fiber paper are recommended to provide the complete incineration of honey samples by thermogravimetry. To confirm these results and to establish the optimized conditions a completely randomized two block design was executed investigating three procedures: thermogravimetry with fiber glass paper at heating rates of 5 and $10^{\circ} \mathrm{C} \mathrm{min}^{-1}$ and standard gravimetry. Only the thermogravimetric method carried out at $5{ }^{\circ} \mathrm{C} \mathrm{min}{ }^{-1}$ presented ash content averages in agreement with those obtained by the official method. In this way, TG/DTG can be indicated as an alternative method to gravimetry for this determination in honey samples.

Keywords: ash contents, honey, thermogravimetry, gravimetry, experimental designs

\section{Introduction}

The ash content in honey is generally low and influenced by the chemical composition of nectar that varies according to the different botanical sources involved in honey formation. ${ }^{1-6}$ It can vary between 0.02 and $1.0 \%$ and the maximum limit allowed by legislation for honey from floral sources is $0.6 \% .^{7}$ Normally, however, ash contents between 0.1 and $0.3 \%$ are found for these

*e-mail: bruns@iqm.unicamp.br honeys. Very high mineral contents (about 1.0\%) are actually encountered only in honeydew honey and ash content is often used to identify this kind of honey. ${ }^{2,8-9}$

The official method for ash content determination in honey is gravimetry. ${ }^{10}$ This technique, in spite of being widely used in routine honey analysis, involves extensive manipulation of sample by the analyst, large sample masses, long analysis times, and sample pre-treatment before incineration that depends on the nature of the constituents present. ${ }^{11-12}$ For this reason there has been a continuous search for new analytical methods for ash 
determination in honey, although few works with this objective have been published in the literature recently. ${ }^{13}$ This stimulates research on new analytical procedures that present more desirable characteristics of routine analysis, such as high analytical frequency, operation ease and greater precision.

Thermoanalytical methods, especially thermogravimetry/differential thermogravimetry (TG/DTG), are already being utilized for ash determination in other foods such as coffee, milk powders, starches, flours and oil seeds showing advantages of shorter analysis times and smaller sample masses, besides dispensing with sample pretreatment. ${ }^{14-17}$ However thermoanalytical methods for ash contents of liquid and paste food products like jellies, syrups and honeys have not been found in the literature. These products often present intense bubbling and spattering effects that hamper complete sample incineration, especially when the pretreatment technique recommended for the gravimetric method is not carried out. ${ }^{11,18}$ These results point out the importance of investigations of thermoanalytical techniques for ash content analysis of honey samples.

In order to establish the best thermoanalysis conditions, operational variables like heating rate, sample mass, gas flux, geometry and material used for the sample container as well as sample characteristics, such as thermal conductivity and particle sizes in the sample must be investigated. These factors must be controlled since they affect the accuracy and precision of the analytical results. ${ }^{19-20}$

In this work, glass fiber paper is introduced for the first time in this kind of analysis although it's use has already been demonstrated to be beneficial in drying pasty food products using microwaves. ${ }^{21}$ Fiber glass paper helps avoid undesirable aspects, like crust formation, of the treated sample. ${ }^{11}$ Therefore, to evaluate this technique for ash content analysis in honey samples a $2^{2}$ factorial design involving heating rate and fiber glass paper factors was carried out. Factorial design results also were utilized to establish the analysis conditions of TG/DTG that produced ash content values more similar to those generally found in floral honey samples (lower than or equal to $0.6 \%$ ) by the official method (gravimetry). ${ }^{7}$ To confirm the design results and the subsequent selection of optimized thermogravimetric conditions a completely randomized two block design was executed.

\section{Materials and Methods}

The honey samples used in the experimental designs were stored until further analysis in plastic bottles at $-18^{\circ} \mathrm{C}$. Also CELM trade-mark fiber glass papers (PAD) were used.
The use of these papers has been approved by the AOAC (Association Official of Analytical Chemists) as being free of ash and thermally stable up to $800{ }^{\circ} \mathrm{C} .{ }^{10}$ The PADs were obtained commercially in the form of $10 \mathrm{~cm} \times 10 \mathrm{~cm}$ squares. To adapt for their use in the thermobalance sample holder, they were transformed to small disks with about $7 \mathrm{~mm}$ diameters using a previously sterilized paper perforator.

Only eucalyptus and citrus honey samples were used to test the thermogravimetric method proposed here since they contain high and low extreme levels of ash contents for most floral species of commercial interest. The eucalyptus honeys normally have higher ash contents owing to the presence of the larger potassium, sodium, chlorine and manganese content, among other elements. ${ }^{2,8}$

\section{Thermogravimetry}

The thermogravimetric (TG) and differential thermogravimetric (DTG) curves of honey samples were obtained with a Shimadzu TGA - 51 thermobalance, using a sample container of alumina $(150 \mu \mathrm{L}, \phi=7 \mathrm{~mm})$, sample mass of about $25.0 \pm 2.0 \mathrm{mg}$, dynamic air atmosphere with flow rate of $50 \mathrm{~cm}^{3} \mathrm{~min}^{-1}$, in the temperature interval of $25-650{ }^{\circ} \mathrm{C}$. The other analysis conditions (heating rate and fiber glass paper) were based on the levels of factorial design and are presented in Table 1.

\section{Gravimetry}

The ash contents of honey samples were determined by gravimetric method $\mathrm{n}^{\circ} 920.181$ of Association of Official and Analytical Chemists. ${ }^{10}$

\section{Experimental}

Factorial design study

The $2^{2}$ factorial design involved two variables: heating rate and fiber glass paper, each at one of two levels using a honey sample. ${ }^{22-23}$ Duplicate TG/DTG curves were obtained in random order for all combinations of factor levels presented in Table 1. The factor effects were calculated from equation 1 :

Effects $=\bar{R}_{+}-\bar{R}_{-}$

where $\bar{R}$ and $\bar{R}$ are the means at the (+) and (-) levels of the factors involved. The (+) and (-) symbols are standard factorial notations and are simply used to differentiate between the levels involved. Their definitions do not affect the interpretation or the conclusions drawn from the results. 
Table 1. Factors and levels of factorial design applied for ash content analysis in honey samples by thermogravimetry

\begin{tabular}{lll}
\hline Factors & Level $(-)$ & Level $(+)$ \\
\hline (1) Heating rate $(\beta)$ & $5^{\circ} \mathrm{C} \mathrm{min}^{-1}$ & $10^{\circ} \mathrm{C} \mathrm{m^{-1 }}$ \\
(2) Fiber glass paper & without & with \\
\hline
\end{tabular}

The factor effects on ash content values were tested for statistical significance by calculating standard errors and $95 \%$ confidence intervals. All the statistical data analyses were carried out using the Statistica and Statistica Industrial System. ${ }^{24}$

\section{Completely randomized block design}

Optimized thermogravimetric analysis conditions from the factorial design are probably indicated by those used for the experiments giving results below $0.6 \%$ since honey samples from floral sources normally have lower ash contents. ${ }^{7}$ Two sets of conditions investigated in the factorial design satisfy this criterion whereas the other two sets result in ash contents well above $0.6 \%$. To confirm these results a two block completely randomized design was carried out for ash content analysis of eucalyptus and citrus honey samples using the two preferred sets of thermogravimetric conditions and the official gravimetric method. The experiments were performed in duplicate to obtain a reliable error estimate. An analysis of variance (ANOVA) and a multiple range test of means (Tukey) were performed to determine any significant differences among the ash content averages obtained by the thermogravimetric and gravimetric methods. Again, all statistical data analyses were carried out using the Statistica and Statistica Industrial System. ${ }^{24}$

\section{Results and Discussion}

All eight TG/DTG curves of eucalyptus honey samples obtained for the factorial design are similar to the one presented in Figure 1 and show a complex thermal decomposition process involving several steps that begin at ambient temperature and finish near $600{ }^{\circ} \mathrm{C}$. The first step of mass loss (Figure 1, I) was attributed to moisture elimination. Second, third and fourth steps (Figure 1; II, III and IV) involved thermal decomposition of other components, carbonization and organic matter oxidation, respectively. The final product, thermally stable at $600^{\circ} \mathrm{C}$, was considered as ash. The attribution of thermal decomposition steps carried out for honey samples in this work agrees with the ones observed for other foods, specially the elimination of moisture and determination of ash. ${ }^{14-17}$

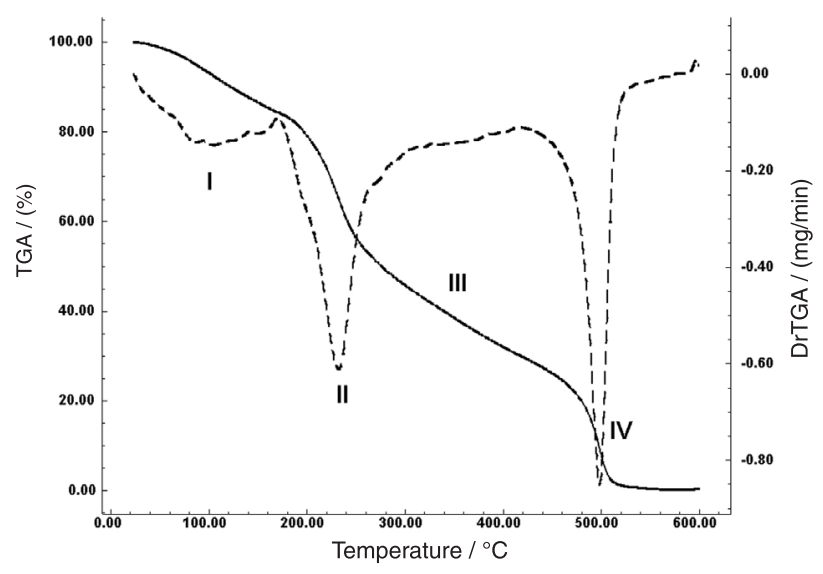

Figure 1. TG/DTG curves of honey sample used in the factorial design obtained under the analysis conditions described in the third experiment of Table 2. ( $\mathrm{I}=$ moisture elimination; $\mathrm{II}=$ other component degradations, III = carbonization and IV = organic matter oxidation).

The factorial design results are presented in Table 2 and the calculated effects are listed in Table 3. No type of sample pre-treatment was applied during the thermogravimetric experiments. Duplicate determinations at each factorial experiment result in an error of $0.06 \%$ for the 0.3 to $1.5 \%$ range of ash contents in Table 2. Gravimetric analysis errors are usually on the order of $0.04 \%$ for these kinds of samples. ${ }^{13}$

Standard error analysis and 95\% confidence intervals demonstrated that all factorial effects are significant (Table 3 ). Heating rate (1) and fiber glass paper (2) for ash content analysis in honey samples by TG/DTG are the more important effects, but the interaction effect between these variables ( 1 and 2), also is significant, having an absolute

Table 2. The $2^{2}$ factorial design results for ash contents analysis in honey samples by thermogravimetry

\begin{tabular}{|c|c|c|c|}
\hline Experiments & Heating Rate & Fiber glass paper & $\begin{array}{l}\text { Ash contents averages (\%) } \\
\pm \text { standard deviations a }\end{array}$ \\
\hline TG1 & $-\left(5^{\circ} \mathrm{C} \min ^{-1}\right)$ & - (without) & $0.629 \pm 0.020$ \\
\hline TG2 & $+\left(10^{\circ} \mathrm{C} \min ^{-1}\right)$ & - (without) & $1.485 \pm 0.113$ \\
\hline TG3 & $-\left(5^{\circ} \mathrm{C} \min ^{-1}\right)$ & + (with) & $0.344 \pm 0.030$ \\
\hline TG4 & $+\left(10^{\circ} \mathrm{C} \min ^{-1}\right)$ & + (with) & $0.488 \pm 0.013$ \\
\hline
\end{tabular}

a standard deviations calculated from duplicate results for the TG/DTG curves for the honey sample used in the factorial design. 
Table 3. Effects and their standard errors calculated for ash contents of honey determined by thermogravimetry for the $2^{2}$ factorial design

\begin{tabular}{lc}
\hline Effects & Estimate \pm standard-error ${ }^{\mathrm{a}}$ \\
\hline Global Mean & $0.736 \pm 0.021$ \\
Main Effects: & \\
Heating rate & $0.500 \pm 0.042$ \\
Fiber glass paper & $-0.641 \pm 0.042$
\end{tabular}

Effects of second order interactions:

Heating rate $\mathrm{x}$ Fiber glass paper

$-0.356 \pm 0.042$

${ }^{a}$ standard-error of effects was calculated using standard deviations presented in Table 2. Confidence intervals at the $95 \%$ level were calculated multiplying the standard-errors by $\mathrm{t}_{4,0.05}=2.776$.

value almost as large as the heating rate main effect. The absolute values of all these effects are almost ten times larger than the standard errors shown in Table 3.

The positive heating rate effect in Table 3 suggests that the use of heating rates of $10^{\circ} \mathrm{C} \mathrm{min}^{-1}$ in thermogravimetry results in ash content averages higher than those obtained with heating rates of $5^{\circ} \mathrm{C} \mathrm{min}^{-1}$ (Figure 2a). High heating rates can result in non-uniform temperature distributions and consequently the formation of hot spots in the superficial layers of the sample leading to incomplete sample incineration. ${ }^{25}$ Lower heating rates appear to be more adequate for the complete incineration of honey
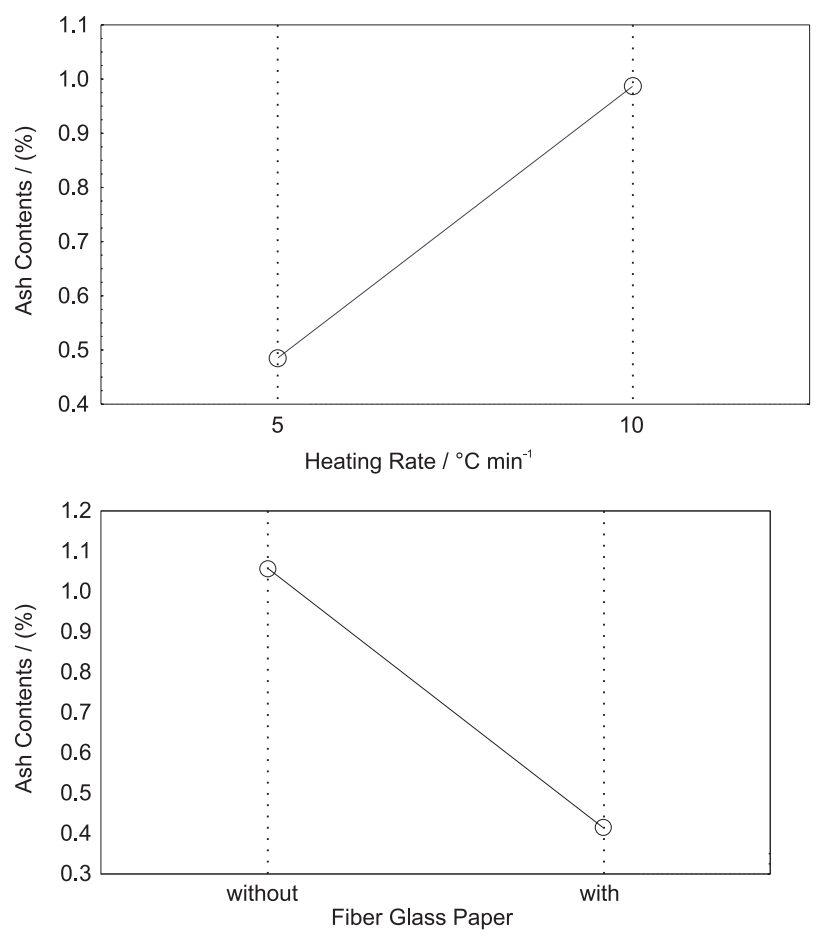

Figure 2. Plot of main effects: (a) heating rate and (b) fiber glass paper. Two level factorial designs assume linearity in all dimensions. samples minimizing the chances of introducing systematic error in the ash content values.

The novel application of fiber glass paper in the thermogravimetric experiments in this work resulted in lower average ash contents relative to those obtained without paper. (Table 3, Figure 2-b). This suggests that the paper improves heat transfer during heating because of a uniform sample distribution in its capillaries (Figure 3) thus facilitating not only the total elimination of moisture (Figures 1-I and Figure 3) but also the carbonization and oxidation of organic matter (Figure 1-III and IV) minimizing bubbling and spattering effects during incineration.

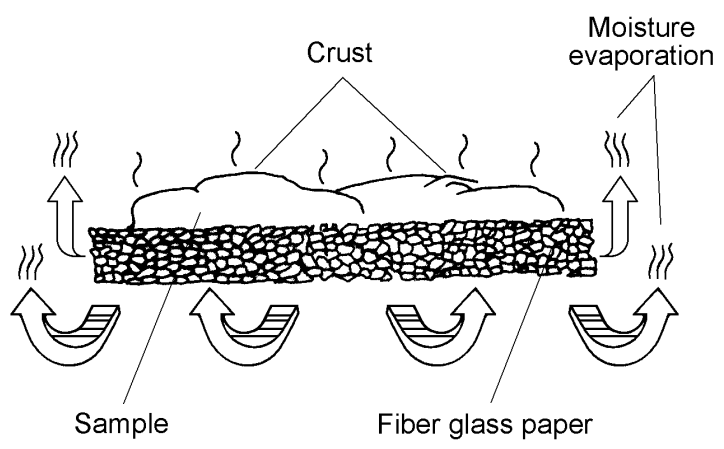

Figure 3. Diagram of fiber glass paper action in drying of rich sugar samples. Since a crust forms water vapors escapes from the bottom through the fiber glass paper as indicated by the curved arrows.

The significant interaction effect observed between heating rate and fiber glass paper (Table 3 ) can be explained more easily by the inclinations of the lines illustrated in Figure 4. The change in ash content increases drastically with an increase in heating rate from $5^{\circ} \mathrm{C} \mathrm{min}^{-1}$ to $10^{\circ} \mathrm{C} \mathrm{min}{ }^{-1}$ without the use of fiber glass paper whereas this effect is negligible when this paper is used. For the TG curves obtained at either 5 or $10^{\circ} \mathrm{C} \mathrm{min}{ }^{-1}$, use of fiber glass paper resulted in lower ash content averages than those registered under the same conditions without it. These results suggest that fiber glass paper aids the carbonization (Figure 1-III) and oxidation processes (Figure 1-IV) of the organic matter minimizing the effects of crust formation, bubbling and spattering during analysis facilitating complete incineration of honey samples. However, without fiber paper it becomes necessary to use heating rates even lower than $5^{\circ} \mathrm{C} \mathrm{min}{ }^{-1}$ in order to obtain similar results to those obtained here with the paper (Figure 4). This is not advantageous since it results in an increased analysis time.

In order to determine which of these two heating rates is more appropriate when using fiber glass paper (experiments TG3 and TG4 of Table 2) to obtain ash contents similar to those encountered using the official gravimetric method a completely randomized block design was executed using eucalyptus and citrus honey samples. 


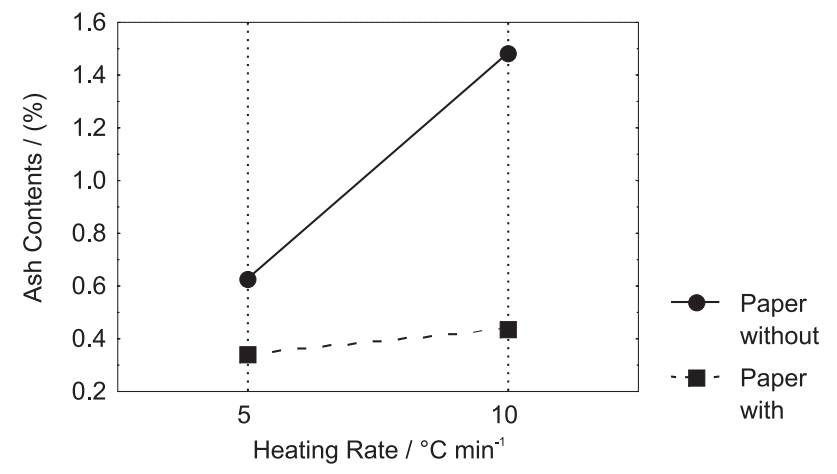

Figure 4. Plot of interaction effect between heating rate and fiber glass paper.

These honey types were chosen because they present very different ash content averages (citrus honeys with lower ash contents and eucalyptus honeys with larger ones) with variations spanning an interval including the ash contents of most monofloral honeys. ${ }^{26}$ The experiments were carried out in duplicate to obtain a reliable error estimate. The ash content averages are presented in the Table 4 and the results of the corresponding analysis of variance (ANOVA) are shown in the Table 5 .

The results of analysis of variance (ANOVA) showed that there are significant differences $(p=0.000)$ between the ash contents of honey samples determined by the thermogravimetric methods and by gravimetry (Figure 5, Table 5). The completely randomized block design also showed a highly significant block effect $(\mathrm{p}=0.000)$ showing the effectiveness of the design for comparing different analytical procedures for samples with large analyte differences associated with different botanical sources. ${ }^{1-3,8}$

Table 4. Ash contents averages \pm standard deviations of eucalyptus and citrus honeys obtained for the randomized complete block design

\begin{tabular}{lll}
\hline Analytical Methods & $\begin{array}{l}\text { Honey Samples } \\
\text { Eucalyptus }\end{array}$ & Citrus \\
\hline TG3 $^{\text {a }}$ & $0.368 \pm 0.015$ & $0.074 \pm 0.005$ \\
TG4 $^{\text {a }}$ & $0.456 \pm 0.016$ & $0.145 \pm 0.005$ \\
Gravimetry & $0.361 \pm 0.015$ & $0.078 \pm 0.005$ \\
\hline
\end{tabular}

a thermogravimetric experiments and its analysis conditions described in Table 2.

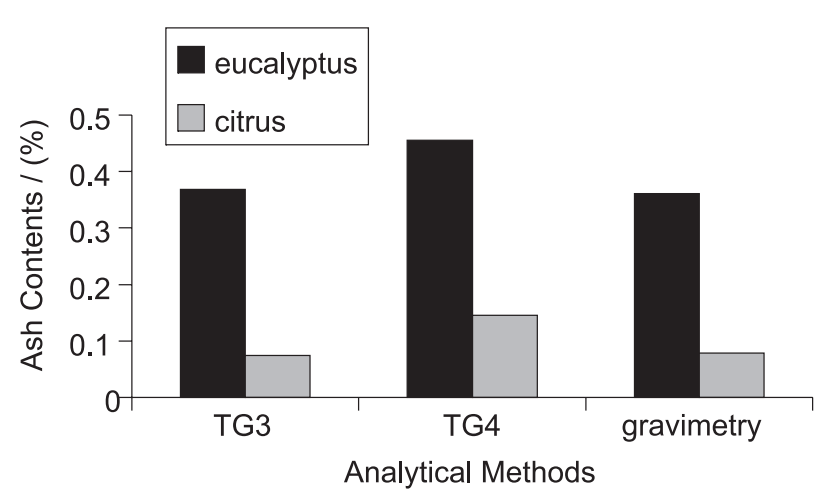

Figure 5. Ash content averages obtained by thermogravimetric and gravimetric methods for eucalyptus and citrus honeys.

Multiple comparisons among means (Tukey-test) at the $95 \%$ confidence level, showed that only the thermogravimetric method carried out at a heating rate of $5{ }^{\circ} \mathrm{C} \min ^{-1}$ (TG3) produced ash content averages in agreement with those found by gravimetry for eucalyptus and citrus honey samples (Figure 5 and Table 4). This shows that besides using fiber paper it is necessary to also use low heating rates to completely incinerate the honey samples by thermogravimetry. This confirms the factorial design results. In addition it was also observed that the TG3 thermogravimetric method can be performed in a direct and dynamic way requiring less analysis time than that for the gravimetric method that involves several sample manipulation steps. Thus, thermogravimetry could be adopted as an alternative method for routine analysis after performing a study of method precision using a larger number of honey samples. In this way, considering that the types of floral honeys chosen present ample variation intervals for ash contents it can be suggested that the thermogravimetric technique can be used as an alternative method to gravimetry for the determination of this physicochemical parameter for any type of floral honey.

\section{Conclusions}

The results of the factorial design showed that lower heating rates are more adequate for thermogravimetric analysis of ash contents in honey since they permit better

Table 5. Analysis of variance (ANOVA) for the completely randomized block design for ash content determination of eucalyptus and citrus honeys

\begin{tabular}{|c|c|c|c|c|c|}
\hline Variation Sources & Degrees of freedom & Sum of Squares & Mean Squares & $F_{o b s}$ & $p$-value \\
\hline Analytical methods & 2 & 0.017059 & 0.008529 & $57.66^{\mathrm{a}}$ & 0.000 \\
\hline Blocks (floral sources) & 1 & 0.263227 & 0.263227 & $1779.56^{\mathrm{a}}$ & 0.000 \\
\hline Error & 8 & 0.001183 & 0.000148 & & \\
\hline Total & 11 & 0.281469 & & & \\
\hline
\end{tabular}

a significant at $95 \%$ confidence level. $\mathrm{F}_{\text {crit }(0.05 ; 2,8)}=4.46$ and $\mathrm{F}_{\text {crit }(0.05 ; 1,8)}=10.1$. 
heat transfer within the sample. The use of fiber glass paper helps not only in total moisture elimination but also in the carbonization and oxidation processes of the organic matter minimizing the effects of crust formation, bubbling and spattering during analysis. The interaction effect between these factors indicated that the effect of heating rate is substantially reduced using fiber glass paper.

The results of the completely randomized block design shows that only the thermogravimetric method carried out with a heating rate of $5^{\circ} \mathrm{C} \mathrm{min}^{-1}$ and fiber glass paper presents ash content averages in agreement with those registered by the official gravimetric method. In view of these results, thermogravimetry can be considered to be an adequate method for determining ash contents in honey since it permits analysis for a large range of analyte variation. Besides this, the thermogravimetric procedure proposed here can be used as an alternative to the gravimetric method for routine analysis since it is easily executed with a smaller analysis times dispensing with sample pre-treatment. However precision studies involving a larger number of samples than those used here should be made prior to adopting this method for routine analysis. These studies are currently being performed in our laboratory.

\section{References}

1. El-Sherbiny, G.A.; Risk. S.S.; J. Food Sci. 1979, 7, 69.

2. Crane, E.; Honey: A Comprehensive Survey, Heinemann: London, 1975.

3. Abu-Tarbousch, H.M.; Al-Kahtani, H.A.; El-Sarrage, M.S.; Food Chem. 1993, 46, 13.

4. Mendes, E.; Proença, E.B.; Ferreira, I.M.P.L.V.O.; Ferreira, M.A.; Carbohyd. Polym. 1998, 37, 219.

5. Al-Khalifa, A.S.; Al-Arify, I.A.; Food Chem. 1999, 67, 21.

6. Andrade, P.B.; Amaral, M .T., Isabel, P.; Carvalho, J.C.M.F.; Scabra, R.; Cunha, A. P.; Food Chem. 1999, 66, 503.

7. Codex Alimentarius Standard for Honey, Ref. Nr. CL 1993/ 14-SH FAO and WHO, Rome, 1993.

8. Crane, E.; Bees and Beekeeping: Sciences Practice and World Resources, Cornell University Press: New York, 1990.

9. Aparna, A.R.; Rajalakshmi, D.; Food Rev. Int. 1999, 15, 455.

10. Association Official Analytical Chemists, Official Methods of Analysis of AOAC International, $17^{\text {th }}$ ed., v. II, Method 920.181, 2000.
11. Nielsen, S.; Introduction to the Chemical Analysis of Foods, Jones and Bartlett Publishers: Boston, 1994.

12. Cecchi, H.M. Fundamentos Teóricos e Práticos em Análises de Alimentos, Campinas; Editora da Unicamp: Brazil, 1999.

13. Bogdanov, S.; Lüllmann, C.; Martin, P.; Von Der Ohe, W.; Russmann, H.; Vorwohl, G.; Oddo, L.P.; Sabatini, A.G.; Marcazzan, G.L.; Piro, R.; Flamini, C.; Morlot, M.; Lheretier, J.; Borneck, R.; Marioleas, P.; Tsigouri, A.; Kerkvliet, J.; Ortiz, A.; Ivanov, T.; D’arcy, B.; Mossel, B.; Vit, P.; Mitt Lebensmittelunters Hyg 1999, 90, 108.

14. Tomassetti, M.; Campanella, L.; Aureli, T.; Thermochim. Acta 1989, 143, 15.

15. Acquistucci, R.; Bucci, R.; Magri, A.D.; Magri, A. L.; Thermochim. Acta 1991, 188, 51.

16. Tomassetti, M.; Campanella, L.; Aureli, T.; Sammartino, M. P.; Thermochim. Acta 1991, 190, 131.

17. Macêdo, R.O.; Moura, O.M. de; Souza, A. G.; Macêdo, A. M. C.; J. Therm. Anal. 1997, 49, 857.

18. Pomeranz, Y.; Meloan, C. E.; Food Analysis: Theory and Practice, Chapman \& Hall : New York, 1994.

19. Wendlandt, W. W. M.; Thermal Analysis, $3^{\text {rd }}$ ed., John Wiley \& Sons: New York, 1986.

20. Haines, P. J.; Thermal Methods of Analysis: Principles, Applications and Problems, $5^{\text {th }}$ ed., Chapman \& Hall: Oxford, 1995.

21. Association Official Analytical Chemists; Official Methods of Analysis of AOAC International, Method 985.26, 1985.

22. Box, G.E.P.; Hunter, W.G.; Hunter, J.S.; Statistics for Experimenters, Wiley Press: New York, 1978.

23. Barros Neto, B. de ; Scarminio, I.S.; Bruns, R.E.; Como Fazer Experimentos, Editora da Unicamp: Campinas, Brazil, 2001.

24. STATSOFT INC., Statistica for Windows, Version 6.0, 2300 East $14^{\text {th }}$ Street, Tulsa, OK, 74104,USA, 1998.

25. Van Dooren, A. A.; Müller, B. W.; Thermochim. Acta 1982, $54,115$.

26. Codex Alimentarius Standard for Honey, Ref. Nr. CL 2000/ 24-SH FAO and WHO, Rome, 2000.

Received: November 24, 2003

Published on the web: October 1, 2004

FAPESP helped in meeting the publication costs of this article. 